\title{
Arab States as Shareholders: Origins and Consequences
}

\author{
Alissa Amico
}

\begin{abstract}
In the Arab world, the role of the state in the social contract has been addressed from various angles: as a provider of employment, as a supplier of goods and services, as a guarantor of security and political stability and more generally as an enabler of economic growth. State-owned enterprises (sOEs), which contribute significantly to all of the above objectives, have not been considered in economic policy making, despite the fact that they are integral to the economic history and competitiveness of most countries in the region. Tracing the history of state ownership from the nation-building process to the present time, this article argues that the scope of state capitalism in most Arab countries is not retreating and that the mechanisms of state control have become increasingly diverse. Across the region, the performance of state enterprises has been highly variable: while some operate with private governance models, those that operate as an extension of the public sector still underperform despite being subsidised. Recent experience demonstrates that in countries that have recently undergone political changes, political appetite or popular support for soe reform is lacking and the prospects for the transfer of positive experiences of soE management in the region are so far limited.
\end{abstract}

The rise of state capitalism has emerged as a topic of growing global public and academic attention, fuelled by the virtual death of the 'Washington Consensus', the rise of economies such as Russia, China, and India, and - finally - the growth of sovereign wealth funds not only as national actors but also as major cross-border investors. While the means and mechanisms of state involvement in the economic sphere are varied, governments have emerged as owners of commercial assets across a range of sectors, challenging liberal economic ideologies that dispute the efficiency of states as economic actors. Far from playing second fiddle to private enterprise, some soes have become behemoths of 
economic power, with 28 of the 100 largest firms globally counting the state as a significant shareholder (The Economist, 2014).

A recent survey of 34 industrialised countries, mostly OECD members, revealed that their governments collectively own 2,111 companies, valued at USD 2 trillion and employing approximately 6 million people (OECD, 2014a). ${ }^{1}$ State ownership in developing economies is even higher: whereas in the OECD area firms majority-controlled by governments are estimated to contribute 3 per cent of total market capitalisation, they represent an estimated 13 per cent of the value of listed equity in emerging economies. The scope of state ownership in the Arab world is higher than in most other developed and emerging markets, whether judged by government participation in capital markets, state ownership of unlisted firms, or other metrics.

Although data on unlisted MENA sOEs is unavailable, our calculations suggest that, currently, 62 per cent of market capitalisation of Arab stock exchanges relates to firms in which sovereign shareholders have 'blockholdings' (10 per cent and above). In fact, of the 6oo largest listed firms, accounting for 97 per cent of the region's market capitalisation, close to 40 per cent have a sizeable number of their shares held by the state (Amico and Ozcelik, 2015). Government ownership is even more prevalent in larger firms, with governments having a considerable stake in 89 of the 100 largest listed firms in the region. While these figures are telling, they exclude the majority of state-owned enterprises, especially in strategic sectors such as petrochemicals, network industries and utilities, as they remain unlisted.

Arab governments are significant owners of both listed and unlisted commercial companies, not only in strategic sectors such as hydrocarbons, mining and minerals, and aviation but also in other, less strategic sectors. And yet, the role of the state as a capitalist in the region, as opposed to as a policymaker, has not been subject to considerable analysis. This represents a curious omission and one that is only partially accidental. Governments in the region do not publish consolidated information on their shareholdings, partly due to the fragmentation of state ownership and the difficulty of collecting data, partly due to the inherent opaqueness of state ownership in some countries. ${ }^{2}$

As a result, the mechanisms and the performance of state capitalism in the Arab world have eluded analysis, with the few existing studies focusing

1 For the purposes of the survey, state ownership was defined as 10 per cent and above.

2 Only Morocco and to a lesser extent Tunisia publish data on the portfolio of state shareholdings and no Arab country publishes information on the performance of soes. 
on privatisation experiences and their impact (cf. Omran, 2009; Haider, 2008; Haider and Dawley, 2008;). After decades of economic dogma that sought to reduce the role of the state in the economy, considering all soes as inefficient and corrupt, the tide has turned and the emergence of successful state-backed firms, notably in the Gulf countries, has prompted a reconsideration of Washington Consensus policies. The global financial crisis has further highlighted the cost of private sector failure, prompting governments to become 'unwilling capitalists' as a consequence of their rescue of faltering firms.

The revolutions and subsequent political transitions experienced in some Arab countries provide a useful political economy backdrop against which the performance of state capitalism can be evaluated. In particular, it appears pertinent to investigate how transitions to democratic governance models, as witnessed in Tunisia, will affect the nature and extent of state ownership. Recent events provide a rich context for examining state ownership in the region considering that soEs are a long-term fixture of MENA economies, many of them having been established to support nation building in postcolonial or independence periods.

In North Africa, the end of colonisation prompted governments to establish local institutions and companies to deliver basic services. In the Gulf, the roots of a number of the largest soes can be traced to the process of the forming of the states themselves, and such enterprises continue to simultaneously perform a range of regulatory, commercial and social functions. For instance, the National Bank of Abu Dhabi - today one of the ten largest Arab banks and top ten listed firms in the region - was established in 1968 to finance domestic infrastructure and also to perform central banking functions.

The emergence of governments as major shareholders followed a somewhat different trajectory in other parts of the Arab world, where it was generally delinked from the process of the formation of the state, instead being motivated by the rise of political ideologies that favoured greater state interventionism, inspired by the Soviet developmental model. This was particularly the case in Syria, Algeria and Egypt, where swaths of economic activity were brought under state control during the nationalisation process in the 195 os to 1970 os.

Nationalisation of strategic assets was also a part of the story of the emergence of soes in the region, especially those in the hydrocarbon field or other strategic sectors. For instance, Saudi Aramco, originally established in 1933 as a result of an oil concession granted by the Saudi government to the affiliate of Standard Oil of California (today's Chevron), was nationalised in 1980. 
Likewise, the Kuwait Petroleum Corporation was fully nationalised in 1975, when the government acquired the remaining 40 per cent stake from British Petroleum and American Gulf Oil.

Only in parts of the Levant, notably in Lebanon and the Palestinian Authority, has the state never emerged as a significant shareholder. Even so, in Lebanon where the government owns less than 30 soEs their impact on the state budget is estimated to be significant. Transfers to Electricite du Liban, the national electricity company, account for 20 per cent of the budget - the second largest item after debt servicing (Hasbani, 2011). Even with such considerable subsidies, the company is unable to provide uninterrupted services to most of the country and its name has become synonymous with public sector failure in Lebanon.

Despite these similarities, the evolution of SOE sectors in the region has differed in important respects. In countries that followed a statist developmental model (Egypt, Iraq, Syria and Yemen), soes were established in a broader range of industries. In Lebanon and Jordan, their establishment was arguably more selective. In the Gulf countries, their emergence was more gradual, only initially resulting from nationalisations and in recent years closely related to national industrialisation and competitiveness strategies. ${ }^{3}$

\section{$2 \quad$ Structure of State Shareholdings}

The initial interest of Arab states in establishing and maintaining soes was supported by a number of well-known academic arguments, notably those advanced by post-World War II developmental economists such as Alexander Gerschenkron who argued that the state needed to take a leading role in capital accumulation and infrastructure development in order to 'catch up' with advanced countries. At the time, local private sector actors were perceived as weak and short-term oriented, interested in catering to consumer demand rather than in long-term investment and national competitiveness.

More recent arguments put forth advocating state interventionism in the economy include private sector coordination failures, fear of the emergence of private monopolies, and 'externalities' in production that may benefit the

3 For instance, the Executive Councils of Dubai and Abu Dhabi and the Emirates Competitiveness Council consider and integrate soEs in their broad strategic orientations. 
whole economy but in which private sector actors may invest less than is socially optimal. In recent years, the systemic risks associated with 'too big to fail' private sector firms have also entered the equation as a motivation for government ownership.

Most of these rationales for state ownership found their echo in the Arab world when governments decided to establish soes, and arguably continue to resonate today, although the structure and challenges of soE sector reform differ by country, as highlighted in Table 6.1. Significant differences can be noted in terms of the number and size of soes in countries of the region and of the mechanisms of control used by governments. In Morocco, the Ministry of Finance reports that it owns 241 SOEs in addition to 44 companies in which the Treasury has a direct interest, some of which are newly created (Semmar, 2012). The Tunisian government holds a portfolio of approximately 200 SOEs, in addition to smaller stakes in 480 firms nationalised following the revolution in 2011. In Egypt, the Ministry of Investment holds a portfolio of approximately 150 soEs in sectors as diverse as insurance and cotton production in addition to over 660 joint ventures between public and private firms as well as an undisclosed number of strategic firms held by sectoral ministries or the military (Bremer, 2012).

The sectoral orientation of soEs is similar in each of the sub-regions comprising the Middle East and North Africa (the Mashreq, the Maghreb, and the Gulf). The range of sectors in which state companies are present owes its variety both to earlier development approaches and to the recent use of soes and Sovereign Wealth Funds (sWFs) as instruments of economic diversification and industrial competitiveness, especially in the Gulf countries. As a result, soEs are mostly concentrated in the minerals and hydrocarbon sectors, service sectors (e.g. utilities, capital-intensive modes of transport, banking, and telecoms) and industrial sectors (e.g. heavy industry operations such as steel and cement) (OECD, 2013).

The extent of state ownership in listed companies - the only available metric of state ownership in the region-indicates high and growing levels of government participation in the economy. Sovereign investment vehicles-historically important players in local capital markets-are reported to have been increasing their participation in capital markets both for commercial reasons and, occasionally, to 'support' market valuations in times of crisis (e.g. in Saudi Arabia in 2006). For instance, the stake of the Public Investment Fund in Tadawul-listed companies had increased by 26 per cent in August 2014 year-to-year, exceeding 20 per cent of the overall market capitalisation. 


\section{Countries Characteristics of state Reform priorities ownership}

Iraq, Yemen, Numerous unincorporated Libya

enterprises; SOEs major recipients of state subsidies; the state seen as an employer of last resort; underinvestment in SOEs

Algeria, Egypt, Large soe sectors owing Syria, Tunisia to the socialist legacy; banking sector historically dominated by soes; high non-performing loans in state-owned banks as a result of lending to other soEs; the state seen as an employer of last resort

Lebanon, Jordan, Morocco

Bahrain, Kuwait, Oman, Qatar, Saudi Arabia, United Arab Emirates (UAE)

\section{Rationalised by privatisation} during the 1980s and 1990s; the state present in selected sectors and is generally not seen as an employer of last resort; soEs are not highly present in the financial sector but remain active in network industries Hydrocarbon soes unlisted; minority stakes in nonstrategic soes listed in part to develop capital markets; new soEs being established in recent years; Sovereign Wealth Funds (swFs) and holding companies increasingly exercise ownership
Corporatisation and valuation of SOE assets; creating mechanisms for reducing redundant employment in the SOE sector; reviewing the soE legal framework; attracting investment in SOES

Rethinking the role of the state in specific sectors (e.g. textiles, agro industries); reorganisation of the state-ownership function; reducing political interference in SOE boards; streamlining legal frameworks applicable to soes

Reviewing state ownership in loss-making enterprises; better co-ordination of the state's ownership function; improving the skills and independence of soe boards; reducing political interference in boards

Improving SOE transparency; preparing listings of equity stakes or debt issuance by some SOEs; consolidating SOE ownership under professional management; reproducing successful ownership experiences 
Unlike OECD countries, many of which have introduced ownership or coordination entities to oversee state shareholdings, the political patronage, and hence the oversight of state shareholdings in the region, remains dispersed. Only Morocco, and to a lesser extent Tunisia and Iraq, have seen some consolidation of oversight in the hands of one or two government entities. Other countries, such as Bahrain and Saudi Arabia, have also witnessed a degree of consolidation of soEs under national sovereign investment funds. For instance, the Ministry of Finance of Bahrain transferred government ownership in a range of large soEs, such as Aluminium Bahrain and Gulf Air, to Bahrain Mumtalakat Holding Company in an effort to restructure the companies and limit subsidisation.

Despite recent efforts towards consolidation, ownership fragmentation of soEs in the region is far from accidental. Sectoral ministries and ministers have often been unwilling to relinquish control of soEs that have proven to be politically useful tools - regardless of their financial performance-and have allowed them not only to control key assets but also to create employment, decide on the provision of essential services, and ultimately intervene in the dayto-day operations of these companies. soes have therefore emerged not only as remnants of nationalisation policies but also, effectively, as mechanisms via which political actors control strategic assets.

In this ownership configuration and in the absence of clarity between ownership and regulatory functions, the role of sectoral regulators has emerged as an important one, with the possible exception of soes operating in monopoly sectors. Yet, apart from a few sectors-such as telecommunications and transport-sectoral regulators remain relatively rare, which effectively exacerbates the conflicts of interest faced by those ministries that own the soes in question. In addition, some sectoral regulators lack the necessary independence, precluding them from effectively exercising their functions. For instance, the Lebanese Telecommunications Regulatory Agency remains dependent on the Minister of Telecommunications and is not in a position to act as an independent regulator since it regulates services directly provided by the ministry. ${ }^{4}$

4 Ogero, the state-owned fixed-line operator, is managed directly by the Ministry of Telecommunications, which is the same body that issues contracts to it. At the same time, the creation of a joint stock company, Liban Telecom, that would effectively corporatise services currently provided directly by the ministry and that could be eventually privatised, was previewed but has not materialised. 
Some regulatory authorities provide services while simultaneously being responsible for sectoral regulation. These include the Dubai Roads and Transports Authority (RTA), which is responsible for the construction and operation of the Dubai metro, and also operates the state-owned taxi service, and inter-city transport and bus services. This creates potential conflicts of interest, especially if state-owned incumbents are to be subjected to competition. Conversely, where independent sectoral regulators have been established (e.g. the Telecom Regulatory Authority in Bahrain or the Supreme Council for Information and Communications Technology in Qatar), their presence has allowed for the emergence of more robust competition between state incumbents and private sector competitors (OECD, 2013).

The emergence of competition frameworks to address potentially competition-distorting aspects of state capitalism is a priority for private sector development and hence for employment creation in the region. Yet the field of competition law in the MENA region has been slow to develop. ${ }^{5}$ Few competition authorities in the region can pursue cases against soEs, which in a number of countries are not included or explicitly excluded from the remit of competition legislation. In the United Arab Emirates (UAE) for instance, soEs are explicitly exempt from the Competition Law, and in Egypt and Oman a narrower set of exemptions for soEs are in place. ${ }^{6}$ Even in countries where soEs are subject to competition law, competition authorities are usually only empowered to prevent price gauging and cartel formation and deal with market access issues.

While the impact of competition authorities on the integrity of state ownership has been mixed, the establishment of anti-corruption watchdogs and the empowerment of state audit courts have played a positive role. The allegations of the misuse of public assets and of crony privatisations, and-more generally-calls for greater public sector transparency in the wake of recent revolutions, have resulted in more active scrutiny of state shareholdings by these entities. This focus on SOE integrity is indeed not surprising and is not limited to the Arab world: a recent global survey of 427 enforcement actions

5 Jordan was the first Arab country to adopt competition legislation (in 2002) and Oman the last to issue a Competition Law (in 2014).

6 In Egypt, public utilities managed by the state are not subject to the Competition Law, while private utilities may apply to the Egyptian Competition Authority for a total or partial exemption. In Oman, a similar exemption is in place: the Competition Law does not apply to public utilities wholly owned or managed by the state. 
related to the bribery of foreign public officials found that employees of soes were the largest target recipient of bribes and that 57 per cent of all bribes were related to procurement transactions (OECD, 2014C).

State audit bodies in most countries in the region are empowered to review the financial and non-financial performance of companies where state ownership exceeds 25 per cent; though few state auditors are authorised to examine all state shareholdings and all types of corruption and potential abuse of public goods. Unlike most of its peers, the state audit court in Morocco (the Cour des Comptes) publicly discloses details of investigations into inefficient and corrupt practises in SOEs and is in the process of conducting a thematic audit of soEs: a first in the Arab world. One of its recent reports heavily criticised one of the large real estate soEs, Al Omrane, which in addition to its purely commercial functions is responsible for building social housing under the Cities Without Slums programme. ${ }^{7}$

In Tunisia, the Tunisian Anti-Corruption Commission, created immediately following the revolution, has uncovered cases of crony privatisations and rigged procurement in soEs, including in large companies such as Tunisie Télécom. ${ }^{8}$ In addition, expropriation measures were taken against assets unlawfully acquired by the former regime and a special Confiscation Commission was created to address this. In Egypt, in various rulings in 2011 and 2012, the courts ruled that the privatisation of formerly public companies was illegal, requiring the acquirers to return shares at the original sale price and to restore employment contracts. A number of other cases are still pending.

In the Gulf countries, governments have recently demonstrated an interest in 'cleaning up' soEs, establishing new oversight entities and allowing corruption charges to be brought and prosecuted. In one of the most publicly followed cases in the region, the CEO of Oman Oil was sentenced in 2014 to 23 years in prison on charges related to bribery in public tender. The same year, the managing director of Galfar Engineering stepped down after being charged with giving bribes to Petroleum Development Oman in exchange for contracts. The former CEO of Aluminium Bahrain was recently sentenced in a London

7 The audit reports state that the company only built 31 per cent of planned social housing units and that only 11 per cent of its KPIs were achieved considering that built units were not allocated to defined beneficiaries of the programme.

8 Tunisie Télécom was found to have accorded a number of large advertising contracts, never approved by its board, to a private company for a total amount of 48 million Tunisian dinars, without following either the public procurement procedures or the internal approval processes. 
court for accepting bribes in return for securing contracts worth in excess of USD 3 billion.

The renewed focus on the governance of soes owes much on the one hand to post-revolutionary expectations and low trust in governments, and on the other to poor performance of soEs as a result of inadequate governance and management structures. While private listed companies have over the past decade been subjected to specific governance requirements in the form of corporate governance codes and regulations, all but a few state-owned firms have escaped such restrictions: only Egypt and Morocco have developed governance guidelines specifically targeted at soEs. ${ }^{9}$

On the other hand, all MENA countries except for Iraq have a corporate governance code or guidelines for listed companies, and a number have also developed specific regulations for banks and insurance companies. This is important since corporate governance guidelines applicable to listed firms are not extended to state-owned firms unless those firms have listed equity, and in some countries-such as the UAE - even listed soes are exempt from the application of the corporate governance code.

Furthermore, governance requirements stipulated in company laws only apply to those companies incorporated under these laws, which excludes most strategic companies as they are incorporated as statutory corporations. This has resulted in governance structures in soes that are, on average, less transparent when compared with listed companies and with their peers globally. To bridge this 'regulatory gap', a number of leading soEs, including $\mathrm{Du}$, the second largest telecom provider in the UAE and Ma'aden, the largest Saudi mining company, have developed internal governance protocols including guidelines for board members and charters for board committees. Some SOE holding companies and sovereign wealth funds with responsibility for SOE ownership have developed guidelines for board members they nominate (e.g. Mumtalakat in Bahrain).

While some, primarily Gulf-based, soes have recognised the value of professionalising their boards and management, this has been far from a universal phenomenon in the region (OECD, 2015). In Tunisia for instance, SOE board members and management are not given the authority to set and implement corporate strategy and refer to the government for all operational decisions. In Iraq and Syria, where SOE reform is at earlier stages-overshadowed by the complexities of ongoing conflicts - addressing 'bread and butter' issues of

9 Tunisia and Oman are currently in the process of developing such guidelines. Globally, recent analysis by the OECD identified 33 corporate governance codes or guidelines specifically aimed at soes. 
corporatisation and the valuation of SOE assets is an even higher priority than the professionalisation of boards and the competitiveness of soes.

\section{The Role of the State in Capital Markets}

Over the past decade, as privatisation has become unpopular in the region, governments have divested few of their stakes in soEs, while at the same time increasing their ownership in a range of public listed firms. Privatisation activity in the region has ground to a halt, victim of allegations of crony capitalism, especially in Tunisia and Egypt - once the top 'privatisers' in the region, ${ }^{10}$ and of the unwillingness of governments to further privatise companies in which stakes were already divested over the past 20 years.

Whereas, globally, a few countries — such as Norway and Spain - are contemplating comprehensive privatisation programmes, few countries in the region including Saudi Arabia, Egypt and Oman seriously consider this as a policy option. In recent years, privatisation activity in the region has been ad hoc and relatively insignificant with the possible exception of the listing of the National Commercial Bank in Saudi Arabia, the second largest Initial Public Offering (IPO) globally in 2014. However, even this transaction saw the allocation of 40 per cent of shares to the Public Pension Agency, a Saudi state-owned pension fund.

Other sovereign institutional investors in Saudi Arabia, including notably the Public Investment Fund and the General Organisation for Social Insurance, are increasing their investment stakes in Tadawul in advance of its planned opening to foreign investors. This reflects the growing participation of sovereign pension funds, insurance companies and banks in MENA capital markets, facilitated by their 'preferred access' to privatisation tranches as part of the subscription process.

An analysis of the 600 largest firms listed on the region's exchanges, accounting for 97 per cent of total market capitalisation, demonstrates that sovereign investors are the largest investor category in all MENA markets with the exception of Lebanon and Tunisia (see Figure 6.1), ahead of family offices. Unsurprisingly, the largest sovereign investment in capital markets occurs in the Gulf countries, where such investors are estimated to control 75 per cent of

10 According to the World Bank's Privatisation Database, Egypt was the largest privatiser in the region from 2000 to 2008 with USD 11.6 billion in privatisation revenues, followed by Morocco with USD 7.9 billion and Tunisia with USD 3.6 billion. 


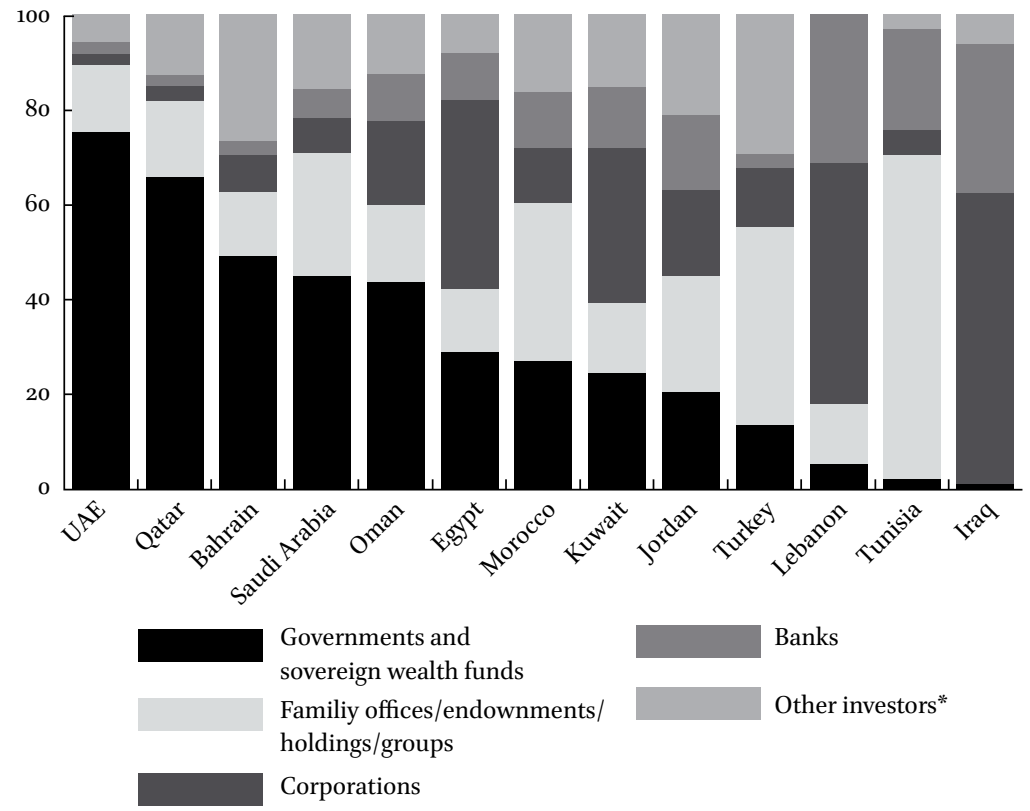

FIGURE 6.1 Value held by institutional investors (as a percentage of market capitalisation by country)

* Alternative investors; asset managers; insurance companies; investments/mutual funds; pension funds.

SOURCE: DATA DERIVED FROM THOMSON REUTERS, COMPILED BY ZEYNEP OZCELIK.

listed companies in the UAE and 65 per cent in Qatar (in terms of their market capitalisation).

As a result, 34 of the top 100 largest listed companies in the region are majority state-owned and a further 55 have significant but not controlling state blockholdings. Overall, 40 per cent of the 600 largest listed firms in the region have the state as a shareholder (Amico and Ozcelik, 2015). These figures are substantially higher than equivalent estimates in other emerging markets, with a few exceptions such as China.

A positive feature of this situation is that sovereign institutional investors in the region tend to act as long-term passive shareholders in MENA equity markets, which are known for their volatility driven by retail investors. However, to the extent that private institutional investor ownership in listed soes is poised to increase following the opening of the Saudi market and the upgrade of the UAE and Qatar to emerging market status in 2014, companies with a mix of government and private investors might find it challenging to reconcile their interests. 
Unlike sovereign investors, which might take into account social or political considerations, foreign pension funds for instance would act as purely financial investors, likely implementing similar engagement tactics as those they have used in their home markets. Although the MENA region has seen virtually no shareholder dissent in recent years, some signs of this tension in state-controlled companies are beginning to emerge. At Emaar Properties, a UAE-based real estate developer, shareholders have recently questioned the involvement of the chairman and other directors in competing firms and their cross-directorships in these (The Arabian Post, 2015). However, investor dissent might be muted by the fact that the returns on investment provided by statecontrolled firms are generally superior to the market average. ${ }^{11}$

\section{5}

\section{Conclusion}

While it is now widely accepted that private sector-led growth is necessary if structural unemployment in the region is to be addressed, state-led development remains a pervasive characteristic of the Arab world, supported by both sovereign financial and industrial actors: SwFs and soes. The ideologies that underpinned the privatisation momentum of the 1980 and the 1990s are no longer seen as relevant to the current socio-economic realities of the region by the general public and by policymakers across the political spectrum. This owes to the fact that privatisations in a number of countries were tainted by corruption and that today mistrust of the private sector looms large.

One manifestation of this is that many Arab governments continue to act as the largest employers of nationals, even as fiscal constraints in oil-importing and exporting countries place significant pressure on public spending. While public sector employment of nationals is a long-standing tradition in the Gulf, growing SOE employment in other countries of the region-including Tunisia, where it is estimated to have doubled from pre-revolution figures-indicates that transitioning these firms to the private sector will require politically unpopular reforms.

At the same time, question marks surround the private sector's capacity to act as a locomotive of economic growth in the Arab world. Many large, familyowned firms in the region, established post-independence, are currently going

11 A recent Morgan Stanley report found that soes in the Middle East, but also in other regions, generate superior returns compared to benchmark indices (Morgan Stanley, 2012). 
through succession changes and their sustainability is being tested. With 65 per cent of all firms in the Middle East valued in excess of USD 1 billion being family controlled (The Economist, 2015), it is anticipated that these transitions will have a significant impact. Few new firms are being created to grow the private corporate sector as the rate of new firm creation in the region is one of the lowest globally, better only than that of Sub-Saharan Africa.

State-owned firms are thus implicitly being accepted as an integral part of Arab economies going forward; as much in the Gulf where experiments with state-led growth have been generally positive as in other countries, such as Egypt and Tunisia, where a few soes are largely not profitable or able to substantially contribute to established social objectives.

On the one hand, the MENA region's reliance on soEs is a consequence of a number of 'inspiring' experiments with state capitalism in the Gulf countries, notably in Saudi Arabia and the UAE. In other countries in the region, the survival of state capitalism is linked to the difficulty of finding an alternative, private sector-led development model as experimentations with privatepublic partnerships and privatisations have fallen short of expectations. Recent global events have further exacerbated mistrust of the private sector, the most recent financial crisis having underscored the risks of having 'too big to fail' private companies and revealed the costs of rescuing them. On other hand, the 2008 crisis in Dubai demonstrated that soes can be rescued and restructured, with contained long-term economic impact.

As a result, for the foreseeable future, reliance on state-owned companies as pioneers of national infrastructure projects and as actors with diverse developmental mandates (e.g. construction of social housing, infrastructure development, employment creation) is bound to continue regardless of fiscal pressures. Post-revolutionary expectations that governments can play the role of fair arbiters of wealth distribution will arguably facilitate government use of soEs as an active development tool.

Examples of the developmental and social activities of soes vary but are visible across the region. For instance, Saudi Aramco, characterised as 'an island of efficiency' within the local administration, has consistently been given mandates related to developing firms in its value chain and occasionally projects beyond its sectorial expertise (e.g. the construction of stadiums). In the UAE, SoEs such as Emaar, Jumeirah Group and the Emirates Airline have been collectively used as a lever for the development of the tourism and hospitality sectors. Unlike Saudi Arabia, the UAE's success in fostering performing soEs is underpinned not by granting independence to the management and boards of individual companies, but instead by linking these soes together in 
competitiveness strategies and through informal networks such as those created by cross directorships.

Regardless of the 'sOE model' applied, even critics of state interventionism would find it challenging to deny the success of some state capitalism experiments in the region, though they would argue that reliance on soEs comes at a cost to private sector growth, notably as a result of the lack of a level-playing field. Indeed, few sectors where soEs are present — such as banking and telecommunications - have been opened to competition, precluding analysis of how statecontrolled firms could fare against their private competitors. Even the telecommunications sector-which in most countries has been a success story of SOE incumbents competing against private firms - has not been fully liberalised. ${ }^{12}$

In addition to the efficiency losses potentially incurred by not subjecting soes to competitive dynamics, the cost of the subsidies or privileged treatment provided to SOEs-while not taken into account in the official statistics - remains sizeable in most countries. For example, in Tunisia where state-owned banks have extended loans on preferential terms to industrial SOEs, non-performing loans are estimated to be in excess of 15 per cent, much higher than in private sector banks (OECD, 2015; Alpha MENA, 2014). Even implicit subsidies can have other negative implications: allegations that Gulf States subsidise their national airlines have resulted in a major commercial dispute with their American and Canadian competitors.

In the long term, attaining competitive neutrality is an important policy objective in the MENA region; not only to improve economic efficiency and the fairness of competition between soEs and private companies, but also for the future development of the private sector. Insofar as key soEs operate in sectors with relatively high barriers to entry, they face few competitive pressures. While private sector competition does not exist in all the sectors in which soes operate, relatively intense competition in some sectors has emerged among state-owned incumbents. ${ }^{13}$

While this intra-SOE competition generates rents for governments and allows the redistribution of rents to social projects, it also generates considerable risks through the high exposure of domestic financial institutions to sOE debt. While the concern that state-led capitalism might cripple private enterprise

12 To stimulate competition without forgoing state rents, some countries have instead fostered competition between two state-owned incumbents (e.g. Du and Etisalat in the UAE).

13 Competition among state-controlled firms has emerged as a distinctive feature of the 'Gulf brand' of state capitalism, in which state-sponsored media, airlines and banks compete quite intensively. 
remains valid, an equally important challenge for the sustainability of state capitalism — as highlighted by the 2009 crisis in Dubai-is adequate risk management at the level of the state to ensure, notably, that risks taken on by soes do not negatively affect the financial sector and overall fiscal stability.

However, given the high cost of bailing out failed private enterprises in the most recent financial crisis, and given public scepticism of private monopolies in the Arab world, the continued reliance on soEs is perceived to be acceptable. In the Gulf, where soes possess 'privatised' management insofar as their governance organs feature representatives of the private sector-reflecting the historical alliances between the state and merchant families-their performance by and large does not give reason to militate for their privatisation. A few loss-making firms ought to be restructured in countries such as Kuwait and Bahrain, taking into account successful soe experiments nationally and in other Gulf Cooperation Council (GCC) countries.

Where soes operate as an extension of the public sector, without the necessary autonomy being afforded to their executives and boards, poor performance has been their common characteristic, both in post-revolutionary countries (e.g. Libya and Tunisia) and in other republics (e.g. Iraq and Algeria). Somewhat paradoxically and for reasons explained above, the weak performance of soEs in these countries has not yet stimulated any demands for SOE reform apart from calls to reduce corruption and nepotism. This suggests that, at least for the near future, soEs will be accepted as a fixture of the new social contract in the region.

For entirely different reasons, neither the Gulf monarchies nor the regimes that have emerged as a result of recent revolutions perceive the need to dramatically alter the terms of their involvement in MENA economies. Indeed, privatisation was not on the agenda of regional governments until 2016, when the fiscal situation of some GCC countries started to deteriorate due to falling oil prices. Elsewhere in the region, the reduction of state ownership anticipated by some observers of the Arab Spring failed to materialise as populations of such countries as Egypt and Tunisia grew disenchanted with previous experiments.

\section{References}

Alphamena (2014) Tunisian Banks: Sectoral Overview (place: AlphamenA, private database accessed on 21 June 2014).

Amico, A. (2012) 'Priorities for Improving Governance and Performance of StateOwned Companies in the Middle East and North Africa', in Amico, A. (ed.) Towards 
New Arrangements for State Ownership in the Middle East and North Africa (Paris: oECD Publishing), pp. 13-52.

Amico, A. and Z. Ozcelik (2015) The Role of Institutional Investors in Developing MENA Capital Markets, unpublished manuscript.

Bremer, J. (2012) 'Transparency of Egypt's Public-Private Joint Ventures', in Amico, A. (ed.) Towards New Arrangements For State Ownership in the Middle East and North Africa (Paris: OECD Publishing), pp. 117-150.

Haider, J.I. (2008) 'Infrastructure Privatisation: A Multinational Review of Five Initiatives in the Middle East and North Africa Region', International Journal of Arab Culture, Management and Sustainable Development, 1 (1), pp. 82-122.

Haider, J.I. and D. Dawley (2008) 'Privatisation and Financial Performance: Can Value be Created by Privatising State Owned Enterprises in the Middle East and North Africa Region?' Journal of Business Valuation and Economic Analysis, 3(1), pp. 1-20.

Hasbani, K.U. (2011) Electricity Sector Reform in Lebanon, Political Consensus in Waiting, CDDRL Working Paper No. 124 (Stanford: CDDRL).

Morgan Stanley (2012) EEMA and Latam Equity Strategy: State Controlled CompaniesWhere to Invest Now, Morgan Stanley research Europe, 24 May.

OECD (2013) State-Owned Enterprises in the Middle East and North Africa: Engines of Development and Competitiveness? (Paris: OECD Publishing), DoI: http://dx.doi. org/10.1787/9789264202979-en.

OECD (2014a) The Size and Sectoral Distribution of SOEs in OECD and Partner Countries (Paris: OECD Publishing), Dor: http://dx.doi.org/10.1787/9789264215610-en.

OECD (2014c) OECD Foreign Bribery Report: An Analysis of the Crime of Bribery of Foreign Public Officials (Paris: oECD Publishing), DoI: http://dx.doi.org/10.1787/ 9789264226616-en.

oECD (2015) Tunisia: A Reform Agenda to Support Competitiveness and Inclusive Growth (Paris: oECD Publishing), https://www.oecd.org/countries/tunisia/Tunisia -a-reform-agenda-to-support-competitiveness-and-inclusive-growth.pdf (accessed on 30 March 2016).

Omran, M. (2009) Post-privatisation corporate governance and firm performance: the Role of Private Ownership Concentration, Identity and Board Composition, Economic Research Forum Working Paper No. 495 (Giza Egypt: Economic Research Forum).

Semmar, A. (2012) 'Corporate Governance of State-Owned Enterprises in Morocco: Evolution and Perspectives', in Amico, A. (ed.) Towards New Arrangements for State Ownership in the Middle East and North Africa (Paris: OECD Publishing), pp. 151-170. The Arabian Post (2015) 'Alabbar in Shareholder Dissent Row', The Arabian Post, 3 April, https://thearabianpost.com/TAP/2015/o4/alabbar-in-shareholder-dissent-row. html (accessed on 29 March 2016). 
The Economist (2014) 'Government-controlled firms, State capitalism in the dock', The Economist, 22 November, http://www.economist.com/news/business/21633831 -performance-state-owned-enterprises-has-been-shockingly-bad-state-capitalism -dock (accessed on 30 March 2016).

The Economist (2015). 'Family Firms: To Have and to Hold', 18 April, http://www.econ omist.com/news/special-report/21648171-far-declining-family-firms-will-remain -important-feature-global-capitalism (accessed on 30 May 2016). 